\title{
The Role of Public Administration in the Hungarian Holocaust \\ General Assessment and Case Study in Historical Social Psychology*
}

\author{
Éva GULYÁS ${ }^{\star *}$
}

\begin{abstract}
The role of public administration in the Holocaust has become an intensely debated issue recently. A large number of researchers have been dealing with the legal frameworks and the means of the administrative apparatus but only a few take up the issue of the moral responsibility of the public servants themselves. This specific aspect is highlighted in the present study, which seeks to answer the question on both theoretical and historical level. Of the theories concerning this topic, the most significant is that of the noted sociologist, late Zygmunt Bauman. The now-classic Polish-born sociologist holds that the major reason triggering the Holocaust is to be found in the characteristics of the bureaucratic machinery but he underestimates the role of anti-Semitism. This study makes an attempt to refute his thesis by highlighting, on the one hand, the activity of the bureaucratic apparatus and the "official anti-Semitism" in original documents, and, on the other hand, the role of antiSemitic prejudices in a local community. The study uses Mezőberény, a small town in Békés County, Hungary, as an example of how the right-wing ideologies set foot in it from the 1930s, and how the extreme right-wing anti-Semitic movements prepared the ground for the Holocaust in 1944.
\end{abstract}

\section{Keywords}

bureaucracy, public administration, Holocaust, anti-Semitism, prejudices in a local community

\footnotetext{
* This article was written in the framework of the Hungarian priority project "Public Service Development Establishing Good Governance" (identification number: KÖFOP 2.1.2-VEKOP-15-2016-00001) at the request of the National University of Public Service.

** The author is an expert of Intercultural Psychology (graduated at the University of Budapest, ELTE), Administration Manager (graduated at National University of Public Service, Budapest), and PhD student at the Doctoral School of Public Administration Sciences (National University of Public Service, Budapest).
} 


\section{Bureaucratic Power and the Activities of Public Servants}

\section{General Frameworks}

Regime and administration are inseparable from one another, since the most common form of modern governance is administration. Administration requires that the superordinate has the commanding power, thus we can state that administration requires domination. It is a management science commonplace that administration takes place in hierarchic organizations, which will be of utmost importance concerning my topic. However, the modern public administration system has numerous other specialties as well. Under public law authorities are limited by three legal points: the office duties and the commanding power to fulfil their duty are permanently divided in the bureaucratic system, and they are strictly limited by the rules of the usage of coercive tools, and constantly regulate the required qualification, the execution and the exercising of rights.

Bureaucracy is a hierarchic, pyramid shaped organization that is in this form a great tool to carry out complex tasks. In its organization system office hierarchy and the principles of bureaucracy prevail, and the sub- and superordinate system, where the subordinate have the right to appeal to a higher body. The rule of law demands that bureaucratic organizations practice administration based on laws and that administration is rational and objective.

It is a strange contradiction that in order to ensure the maintenance and protection of the democratic system, there is a need for bureaucracy. On the other hand, democracy and bureaucracy are against one another. Bureaucracy can be seen as the consequence democracy; however it is obvious that democracy is the greatest obstacle of the birth of a purely bureaucratic power. However democracy cannot stand in the way of the growing power over people practiced by bureaucratic organizations. Bureaucratic administration never exposes itself to criticism and tends to hide its information and activities, and also strives to exclude the public from management, thus serving as a perfect base for a tyrannical rule. ${ }^{1}$

Office routine, the main task of bureaucracy, is carried out by an apparatus of subordinates. Officials are automatically required loyalty in exchange for their stable livelihood. Loyalty in the modern world means being loyal to a specific goal; and behind this goal there may be an ideology or a cultural value. As for the officials, we see that they are striving to gain social appreciation. In their circle, we can distinguish between the 'clear type' subordinates and the ones appointed by the subordinates of the rule; the latter ones are dependent on the operating mechanism parties. Bureaucratization is stimulated by the growing office tasks, and even more so when solving a new task demands more from the officials and are also required to be more efficient in quality. The members of office bureaucracy can be compared to mechanic machinery, where the staff does a constantly accurate, rapid, and discrete work. ${ }^{2}$

1 WEBER, Max: Witrschaft und Gesellschaft. Grundriss der verstehenden Soziologie, Frankfurt am Main 2005, 162-166; 721-723. [Hungarian edition: Politikai szociológia. Politikai közösségek. Az uralom, Budapest 2009, 144-145].

2 Ibidem, 160. [Hungarian edition: 119-122]. 
Bureaucrats on the bottom of the career ladder usually have the impression that their work is uninteresting and is only about the execution of the everyday tasks, and they may feel that they have no word in their everyday activities; it is only the leaders on the top who can set their actions. ${ }^{3}$

\section{The Connection between the Holocaust and the Administration}

Zygmund Bauman, Polish sociologist, has a similar view to Max Weber about the operation of bureaucratic systems. Both claim that it is the capitalist economy's turnover that demands that the administration is smooth and intensive while also transparent and accurate. Both regard the increasing bureaucracy as an unavoidable historic tendency and a somewhat necessity. In Bauman's view, on the one hand it is connected to the political efforts to create a permanent army and on the other to the financial efforts related to it. Eventually he argues that the spread of bureaucratic organization stems mainly from the technological development. ${ }^{4}$

It is a general principle that bureaucracy does not allow officials to manage tasks arbitrarily or to practice personally motivated bias: the norms of office behaviour are ruled by the actual goals together with a devotion to rational aims. When administration is entirely bureaucratized, power - according to the classics - becomes practically irrefutable. Officials become the cogwheels of inconstantly moving machinery that sets what and how things can be done. Officials often become the prisoners of bureaucratic activity simply by struggling for maintaining themselves financially. They are practically indispensible, because the planned unity is only possible when everyone performs their part. Such a system is capable of operating impersonally and for anyone; it is enough that there is a change at the top and the bureaucratic apparatus continues to carry out the will of a possibly evil power. ${ }^{5}$

Since its introduction the term, "bureaucracy" has been used with a negative connotation and the same is true when we connect it to the Holocaust. American sociologist, Paul du Guy, has tried to confront this critical viewpoint and the most common arguments against bureaucracy. According to him, the Holocaust was made possible, when the racist beliefs of the Nazi ideology conquered obeying the laws, the basis of bureaucracy. ${ }^{6}$ Paul de Guy agrees with Bauman that only the advanced bureaucratic institutions of the modern societies made such horrible atrocities possible as the Holocaust. The killing of six million people was only possible in a system, where moral responsibility was not an issue. His theory suggests that the Holocaust was not an animalistic sign of violence; it was made possible merely because of the creation of a rational bureaucratic institution system, where the execution of tasks were separated from their consequences. Bureaucrats and soldiers did not question the sense of their assigned tasks; they solely focused on the precise

3 Cf. DU GAY, Paul: In Praise of Bureaucracy. Weber - Organization - Ethics, London 2000. [in Hungarian: DU GAY, Paul: Valóban olyan rossz dolog a bürokrácia?, in: Szociológia, GIDDENS, Anthony, Budapest 2008, 495-496].

4 BAUMAN, Zygmunt: Modernity and the Holocaust, Cambridge-Maldon 1989, 102-104. [in Hungarian: A modernitás és a holokauszt, Budapest 2001, 151-152].

5 See also WEBER, Witrschaft und ..., 716-718. [Hungarian edition: 139-142.]

6 Cf. DU GAY, Paul: Bauman's Buerau: 'Modernity', Identity, Ethics 35-61. [i.m. 495-496]. 
execution to the best of their abilities. Bauman clearly absolves the perpetrators from personal responsibility by saying they were only part of a bureaucratic system. The German government was filthy with the Jews in a way that was and is unprecedented. ${ }^{7}$

Asking a few questions may stir up trouble ie. what kind of people were the ones executing such a genocide and what circumstances made otherwise moral people to let this happen. We may even state that modern civilization was not sufficient, but necessary condition for the Holocaust. In order to organize and execute it, the technological advancement of the industrial society was not enough; the effective organization of the bureaucratic society was also required. ${ }^{8}$ Although Bauman does not offer an exact definition of his understanding of modernity, it is "obvious that he considers [modernity] to be characterised by constantly progressing technology becoming the centre of civilisation, and, perhaps most importantly, by bureaucratic culture, almost lifestyle, whose consequences included the "Endlösung". Bureaucratic culture stands for a hierarchically regulated way in which certain decisions are taken: the decisions that jointly establish the Gestalt of public policy. In Bauman's view, holocaust showed the negative side of modernity, not the one described by optimistic positivist sociology which saw modern civilised society as the curb of mass murder." 9 Bauman himself formulated it in the following way: "Though modern civilisation was not a sufficient criterion for the Holocaust, it can certainly be claimed that it was a necessary condition for that. Without it, the Holocaust would have been unimaginable." 10

Office hierarchy was permeated by the punctuality of the officers and the insensitivity of the army. Setting up the camps and extermination centres was made possible by the industry, while the Nazi party and its politics served the official's ideology and mission-centeredness. A well-organized and gigantic bureaucratic apparatus carried out genocide, while all they focussed on was the correct office routine, proper wording and obedience to the law. ${ }^{11}$

\section{Obedience as a Virtue}

Thanks to the advancement of bureaucracy we witness two parallel processes: the outstandingly accurate work sharing and the vanishing of moral responsibility. The personal morals of public servants became irrelevant compared to the technical achievements of the organization. Under strict pressure from the superordinates, they continued to perfectly focus on their tasks, in hope of a promotion. If the question of moral responsibility emerged during their service, they fought it down by the depersonalization of the aims writes Bauman. They created a distance between human beings and labour, where humans were transformed into quantifiable data. A "cargo" of which's financial effect was taken into consideration can be easily understood as a quantifiable data, and not as a group of

7 BAUMAN, 15-18. [i.m. 38-42].

8 BROWNING, Christopher R.: The German Bureaucracy and the Holocaust, in: Genocide: Critical Issues of the Holocaust, GROBMAN, Alex - MILTON, Sybil - LANDES, Daniel (eds.), Los Angeles 1983, 148. As quoted by Cf. BAUMAN, 13. [i.m. 35].

9 Cf. BAUER, Yehuda: Comprehensive Theories: Zygmunt Bauer, Jeffrey Herf, Götz Aly, in: Holokauszt: történelem és emlékezet. [Holocaust: History and Memory], KOVÁCS, Mónika (ed.), Budapest 2005, 76.

10 Cf. BAUMAN, 13. [i.m. 35].

11 Ibidem 102-105. [i.m.: 151-154]. 
sentient people. Originally bureaucracy is coded in a way to always seek for the optimal solution. It is part of its job to not to make a difference between people (clients). We see that in order to increase efficiency and decrease the costs, it is willing to do the same in connection with human beings and inhuman 'objects'. ${ }^{12}$

The department responsible for the genocide of the European Jews was formally called Main Economic and Administrative Office in the Headquarters of SS. The name did not cover the whole truth but still referred to the purpose of its activity. It was not different from any real economic or administrative activity; the staff was involved in planning, controlling and supervising, as in any other instance.

In light of the Nazi ideology Hitler set out to cleanse the German Reich from Jews, but he did not specify as to how this will be reached. The idea of the forced migration of the Jews from the continent has also emerged, but it would have needed too much money and time; the choice of physical destruction proved to be more efficient. After this decision was made it was all about the cooperation, the adequate technical tools and the resources of the offices of the European countries. First and foremost office bureaucracy was needed in order to implement the Holocaust. ${ }^{13}$

Before World War II, there is no record of a genocide that was carried out with the help of the 'scientific' theories of modern administration. One of these scientific theories is the honour and self-esteem of the public servant, when they are open to a self-sacrifice taken as a virtue, thus placing the will of their superordinates ahead of their morals. ${ }^{14}$

As people say, officials profit from this ability. We despise the clergyman if he preaches against his conviction, but the judge is respected who makes a decision against his will but in accordance with the law and we acknowledge the public servant who - even when it is against their will - executes the directions. Thus officials form a belief that only the inner rules are accepted as a guarantee for their actions, which sometimes contradicts their own moral sense. This contradictory process is called the transformation of administrative work to moral sense.

During the Holocaust by using bureaucracy a social behaviour was created which made morally not corrupted people kill. It is crucial to remember that most participants of the genocide contributed to the mass murder indirectly. Most of them only took notes, made phone calls, prepared plans and participated in meetings while sitting behind their desks. ${ }^{15}$ Without doubt, the accumulation of such minor actions paved the way to the elimination of six millions of European Jews.

However, bureaucracy is not only a tool but it has its own logic and pace. ${ }^{16}$ The more satisfaction the officials drew from the leaders, the more eager they were to look for new areas, where they could prove the achievements of their perfect work mechanism. Functionalists

\footnotetext{
12 Ibidem, 102-104. [ i.m. 151-153].

13 Ibidem 15, 104-107. [38, 154-156].

14 Cf. WEBER, Max: Politik als Beruf (1921), Tübingen 1988. quotations from: Berliner Ausgabe 2016, 32. [in Hungarian: A tudomány és politika, mint hivatás. Medvetánc füzetek, 1989, 82].

15 HILBERG, Raul: The Destruction of The European Jews, New York 1983, 1024, as quoted by BAUMAN, 24. [i.m. 49].

16 ARENDT, Hannah: The Origins of Totalitarianism, Cleveland and New York 1968, 185. [in Hungarian: A totalitarizmus gyökerei. Race and bureaucracy, Budapest 1992, 225-261].
} 
claim that the objective of the German political leadership and of the bureaucracy were not identical, because while bureaucracy's goal was to completely comply, the politicians aimed at destroying the Jewish people. However, the result will be the same if they get the tool to have the same objective as the leaders. We can see clearly the same when the means and tools blur into one another in the example of the deportation of the Hungarian Jews. In 1944, it was already foreseeable that Germany will lose the war but even though the eastern front was only three miles away, they launched the Hungarian transports, which required great resources taken from the military field.

Adolf Eichmann, the main organizer of the Hungarian Jewish deportations prior to admitting his crimes held on to the idea that he solely executed the orders he had been given and he wasn't only following orders, but the law. Using Kant's categorical imperative, he wanted to prove his innocence and lessen the responsibility by portraying himself as not an independent decision maker, but as a cogwheel of bureaucracy. "Do as the maxima of your will can act as a principle of general jurisdiction. "17

Nevertheless, Eichmann's explanation for becoming the victim of bureaucracy cannot be accepted, since he was not a simple public servant, but belonged to the military leadership; and even though he was Himmler's subordinate, he still had the right to make decisions and orders in his field. There would be no war criminals and Eichmann would not have been sentenced to death, if it was not true that compliant behaviour can also be guilty, when it is in no contradiction with the ethical norms of the time. The ethical norms that inhibit us from killing people without any or for a trumped-up cannot be repealed; the validity of these norms can only be suspended by society - as it happened in the era of the Holocaust. ${ }^{18}$

There are numerous examples of officials, who found that executing tasks contradicted their moral beliefs and others, who risked their lives in order to save the victims of the Holocaust, or who could not execute their tasks with devotion. American historian, Christopher R. Browning examined the work mechanism of four clerks, working in the Department of Jewish Affairs (D III). Two of them were satisfied with their jobs and the other two have requested reassignment. Before having relocated themselves, they had been perfect in completing their tasks. Although they did not reveal their reasons, they tried to use every means they had to be assigned to another position. ${ }^{19}$

\section{Functionalist and Intentionalist Trends}

While in Western Europe there were two different terminology systems to understand the Holocaust (called functionalists and intentionalists), "in Hungary - as Krisztián Ungváry writes - the question of the interpretation itself has not provoked any public interest." 20

17 See KANT, Immanuel: Grundlegung zur Metaphysik der Sitten, Frankfurt am Main 1977. [in Hungarian: KANT, Immanuel: Az erkölcsök metafizikájának alapvetése. A gyakorlati ész kritikája. Az erkölcsök metafizikája. Gondolat, Budapest 1991].

18 Cf. ARENDT, Hannah: Eichmann in Jerusalem, New York 2006, 136. [in Hungarian: Eichmann Jeruzsálemben, Budapest 2000, 158.]

19 BROWNING, 190. As quoted by BAUMAN, 13. [i.m. 272.].

20 UNGVÁRY, Krisztián: A Horthy-rendszer mérlege. Diszkriminció, szociálpolitika és antiszemitizmus Magyarországon 1919-1944, Pécs-Budapest 2013, 6. 
Also considering the role of bureaucracy, there is a clear split between the two groups. Functionalists place social structures generated during the crisis and the political and economic background as well as the bureaucratic machinery in the center researching the motives of the Holocaust, while intentionalists emphasise that the ideology of the Nazi party was the main reason, while modernism and bureaucracy were undoubtedly additional factors. The Nazi ideology, without doubt, was affected by anti-Semitism. The illustration of the two positions:
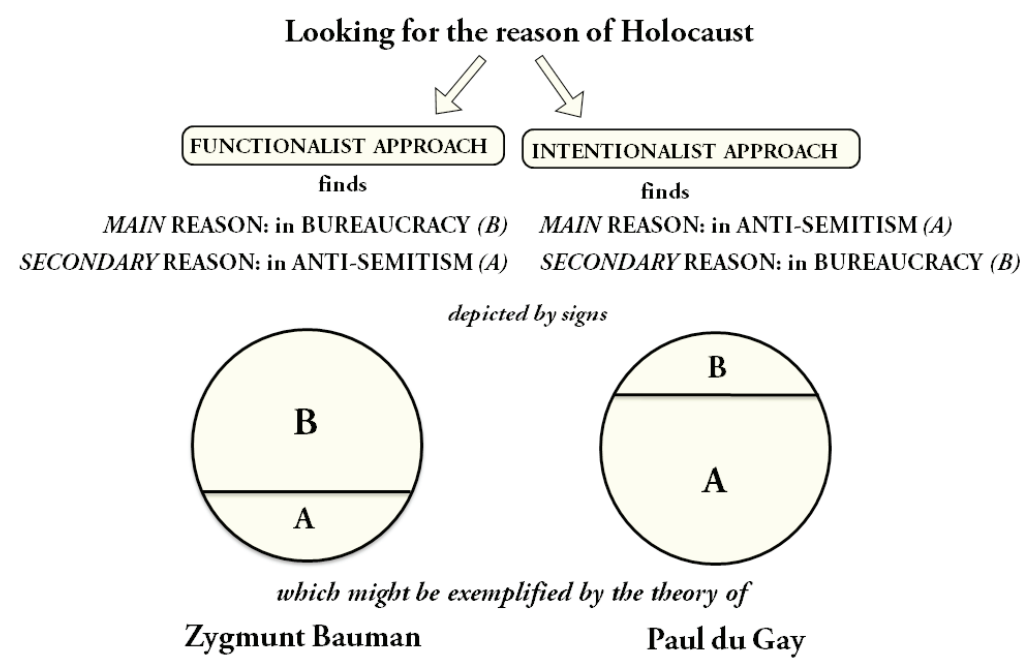

It is easy to identify with Bauman's theory - in my view - in terms of the moral issues, but in the following part of the study I refute the exclusive role of bureaucracy in the functionalist theory. I agree with the statement that without the "harmonic co-operation" of bureaucracy, the Holocaust could not have happened. However, in my view, we cannot ascertain that the central cause of the Holocaust was the bureaucratic system created by modern civilization. The anti-Semitic sentiments of officials and society absorbing the ideology designated by the ruling party played an equal part, just as the machinery of bureaucracy. It is impossible to differentiate between the two factors - at least in the sense that both played a certain role, and in the absence of (any)one of them, the tragedy could have been avoided.

According to Bauman, "anti-Semitism is not an answer" to the Holocaust. ${ }^{21}$ "Anti-Semitism per se does not explain the Holocaust (to put it more generally, hatred per se is an insufficient answer to any genocide)." 22 Bauman puts the most emphasis on bureaucracy because, according to him, it is a necessary and sufficient condition for the Holocaust, while anti-Semitism is a necessary but, per se, insufficient condition for that. Therefore, bureaucracy as a factor was given a more emphatic (central) role in his theory.

Thus, among the factors of anti-Semitism and bureaucracy, we can observe degrees according to which factor we consider of central, or main cause and which of secondary in their role in the process of the Holocaust.

21 Cf. BAUER, 77.

22 Cf. BAUMAN: op. cit. 35-38. [i.m. 59-60]. 
Therefore, according to Bauman, the factor of modernity (and bureaucracy) was given the most emphatic role which, as a matter of fact, is a system created by modern civilization. Last but not least, he also mentions anti-Semitism as playing a certain role but he attributes lesser emphasis to it.

His statements are not entirely confirmed. It is true that Hitler's dictatorship emerged from a modern and in the beginning democratic Weimar Republic, but France and Great-Britain were similarly modern states and yet they did not start initiate the/a Holocaust. ${ }^{23}$ Naturally, I am not saying that without these elements the Holocaust would not have happened in the above-mentioned European states. ${ }^{24}$

Bauman primarily discusses the status of the German clerks and he draws conclusion to bureaucracy as a whole. In his analysis, he does not take it into account that the Holocaust did not take place in only within the German Reich, but in many other countries where the cooperation of the local authorities was also needed. Even if we accept the inertia of the German bureaucracy, the Polish, Czech, Romanian and Hungarian mayors, local officials, the gendarme and police officers do not fall in the same category, as they were not directly under German control.

\section{The Role of Hungarian Bureaucracy in 1944}

After the above points, let us examine the role of Hungarian administration in connection with the deportations. In order to provide a complete picture, I will analyze the public administration through leading politicians, the central administration, law-enforcement agencies and rural administrative systems.

\section{Political Leaders and Central Administration}

In this part of the paper I will discuss the role of politicians who had decisive role in the Hungarian leadership before and during World War II. After the resignation of the non-German friendly Kállay government, governor Miklós Horthy decided to stay in his position as head of state. Horthy reached three things with his participation in the Sztójay government: with the legitimization of the occupation Hungary was made at the service of the Germans, he maintained order and that the military production is uninterrupted. Horthy's role has several proofs. The Council of Ministers registered the following on 29 March 1944: "According to the Prime Minister, that His Serene Highness the Regent has given a free hand to the government in connection with Jewish decrees and does not wish to exercise his influence." 25 After the establishment of the new government, they immediately started

23 See for example Yehuda Bauer's question: "[w]hy was it possible for the regime of Hitler to rise [the regime] in Germany and decide that they kill the Jews", see BAUER, 80.

24 See in details the example of French: "Izraelites got the worst. German authorities and the vichy government made discriminate steps from the summer of 1940, which excluded them from French communities and prepare their extermination. (...) The number of the casualties of racial persecution is around 85 thousand." Franciaország története, 2. kötet [History of France. vol. 2.], DUBY, Georges (ed.), Budapest 2007, 296-297.

25 A Minisztertanács 1944. március 29-i jegyzőkönyve [Minutes of (Hungarian) Cabinet Council of 29 March 1944, see KARSAI, Elek: Vádirat a nácizmus ellen. 1 kötet, Budapest 1967, 73. 
to round up Jewish 'workers'. Veesenmayer, Hitler's personal representative in Hungary conveyed a message to the German Minister of Foreign Affairs, Ribbentrop that "it is not only the cooperation of Hungarian Home Office but also Horthy's consent was ensured." 26 Apart from the regent the most important politician was the prime minister, who at that time was Döme Sztójay. Sztójay not only knew that the Germans supported the radical solution of the Hungarian Jewish question, but he himself also urged the solution of the Jewish problem. "He would consider it right - he claimed - if Hungary would not wait for the Germans to bring up this question, and would speed up the guard changing process and would relocate the majority of its Jewish communities the occupied Russia." He also did not keep it as a secret that 'deportation' truly meant extermination. ${ }^{27}$

From among the officers of the Sztójay government László Baky, state secretary, head of the political department of the Home Office and László Endre, state secretary, the head of the administrative department need to be noted as the ones bearing the main responsibility for the swift execution of the deportation. Baky claimed that he issued the decree of the deportation of Jewish people on 7 April 1944 because László Endre asked him. Endre, on the other hand, said that the regent had agreed to the implementation of the operation reasoning: "the sooner the operation ends, the sooner the Germans leave the country" ${ }^{28}$ Endre's bureaucratic and anti-Semitic practice meant the flexible and selective application of the regulations. In a number of cases he punished people by using trumped-up and outdated regulations. Jewish without a Hungarian nationality were expelled in an accelerated procedure and made arrests on his own initiative. ${ }^{29}$ He verbalized the essence of his public administration in an article in 1928: "The paragraphs do not provide a legal solution to every situation, thus the officer is often faced with a situation where without a legal base he must interfere based on his common sense and compassionate heart. Where the national interest and social needs require [...] public administration [...] is a lot less abstract, and its entire nature needs to adapt to the pulsating and constantly changing life. Decisions made in such spirit would usually be approved by higher fora if they wouldn't find themselves facing against the open or secret powers, which hinder the legally not correct but the rightful and necessary handling of the case." 30

There are a number of documents proving that Horthy gave his consent to having Hungarian Jews being used in German military environment and this consent was later abused for the 'final solution'. Andor Jaross Home Secretary appointed László Endre as the head of administration, because he knew that he was a renowned expert in Jewish issues. Endre

26 BRAHAM, Randolf L.: The Politics of Genocide: The Holocaust in Hungary. Detroit - Michigan 2000. In relation to it, see also GERLACH, Christian - GÖTZ Aly: The Last Chapter. Realpolitik, Ideology and the Routine Killing of Hungarian Jews 1944/1945, Stuttgart - München 2002, 87-118.; GÖTZ, Aly: Hitler's Folk State: Robbery, Ethnic War and National Socialism, 2012.; SZITA, Szabolcs: Együttélés, Üldöztetés, Holokauszt Budapest 2001, 178-188.

27 KARSAI, Elek: A budai vártól a gyepúig. 1941-1945, Budapest 1965, 203-206.

28 MACARTNEY, Carlile Aylmer: October fifteenth. A history of modern Hungary, 1929-1945, vol. 2, Edinburgh 1956-57, 283., as quoted by BRAHAM: The Politics..., Chapter 3.: The Road to Destruction: Horthy's Consent to the Delivery of "Jewish Workers", 39. [in Hungarian: i.m. (2003) i.m. 49.]

29 UNGVÁRY, 155-156. This remark refers to László Endre's period as chief constable and deputy-lieutenant. 30 VÁGI, Zoltán: Endre László. Fajvédelem és bürokratikus antiszemitizmus a közigazgatási gyakorlatban, 19191944, in: Tanulmányok a holokausztról. 2. kötet, BRAHAM, Randolph L. (ed.), Budapest 2002, 132. 
was with a close friend of Adolf Eichmann, who was the omnipotent leader of the Jewish deportations in Hungary. Once he made a comment to Eichmann that "he would eat up Jews with pepper". When Jaross asked him to handle the Jewish question in a special way, Endre took out a thick folder from his desk: "Every necessary regulation plan can be found in this folder; I prepared everything" - he said. ${ }^{31}$ László Baky was an openly antiSemitic member of the Hungarian officers corps, he participated in the organization and management of a number of Nazi parties; and as a member of the parliament he became a fervent advocate of anti-Semitism. Baky said it very simple: "My task is the complete elimination of the left-wing and Jewish trouble makers." 32

László Endre said on 1 April 1944 to the Pester Lloyd magazine that the Hungarian public has been demanding the settling of the Jewish question for almost a quarter of a century. As for the Hungarian race, Jews are not needed morally, intellectually or physically. Being aware of this recognition, it is essential to find the solution that shuts Jews out from the lives of Hungarians. ${ }^{33}$ Baky even brought the attention of the Hungarian armed forces to the co-operation with the German authorities in a ordinance: "When in my present decree I wish to create calm, I also wish to set a guideline to behaviour between the German armed forces, the police and the Hungarian authorities to ensure their harmonious cooperation. "34 The confidential conference held on 7 April 1944 in the Home Office, gendarmerie officers were also informed about the following anti-Jewish procedure. ${ }^{35}$

\section{The Role of Law Enforcement Authorities}

Law enforcement authorities in Hungary operated - just as today - in the framework of the Home Office. A number of the home office departments dealing with police cases were also responsible for questions concerning Jews. Department VII (public security) was special, and it had three other sub-divisions: public security subdivision (VII/a), organizational subdivision VII/b and the National Central Authority for Controlling Foreigners (KEOKH) (VII/c). The organizational subdivision played the main role in setting up the ghettos and in the planning and execution of the deportation, which had overtaken the control over the Jews in the whole country. The ministry's political department was reorganized and was removed from the control of the police headquarters and was renamed (the Gestapo's

31 KARSAI, Elek: Ítél a nép, Budapest 1977, 200.

32 BRAHAM, The Politics... , Chapter 3.: The Road to Destruction: The Sztójay Government and Its Agencies, 44. [in Hungarian i. m. (2005) 54.].

33 Pester Loyd [Hungarian daily paper in German] 1944. április 1. quoted in Vádirat a nácizmus ellen [Indictment against Nazism] cited edition [id. kiad.] 200.

34 Magyar Nemzeti Levéltár Békés Megyei Levéltára (Hungarian National Archives of Békés County), A Belügyminisztérium körrendelete a magyar hatóságok és a német fegyveres alakulatok között kialakítandó együttmúködés irányelveiről (Order of the Home Office about the guidelines of cooperation between the Hungarian authorities and the German armed forces).

35 During the meeting, a report was created and the secret order was published. See Vádirat a nácizmus ellen [Indictment against Nazism] cited edition [id. kiad.] 1. kötet [vol. 1] 123-127. About the activity of Endre László, Baky László, Jaross Andor see also Az Endre-Baky-Jaross per, KARSAI, László - MOLNÁR, Judit (eds.), Budapest 1994. On post-war criminal procedures (in Canada) concerning Hungarian Holocaust see TAKÁCS, Péter: Hostis humani generis. A joghatóság és a büntethetőség problémái a Finta-ügyben, in: Fundamentum [Budapest] 2001/4, 21-37. 
equivalent) State Security Police, placed under state secretary Baky's control. It was given the number IV/4 similarly to Eichmann's special force, and they took an active part in the expropriation of Jewish properties. Baky led division XX of the Home Office and controlled the police and the gendarmerie and was in a close relationship with lieutenant colonel László Ferenczy, who was a gendarme appointed to the execution of the deportation program. Division XII - because of the disguised relocation of Jews - was called the housing department; took a direct part in the concentration and displacement of Jews, following the orders of László Endre. ${ }^{36}$

Deportations started on 16 April 1944 by the establishment of ghettos in the rural areas. The gendarmerie maintained the order in the rural areas, and thus became the body that set ups the ghetto and led the deportation program under the control of the Home Office and the Ministry of Defence. The Royal Gendarmerie of Hungary had the most important role from among the Hungarian authorities, the proceedings of the People's Court after World War II can attest that. ${ }^{37}$

At this time, Hungary was divided into ten gendarmerie districts, each lead by a gendarmerie lieutenant colonel. The number of lieutenants was about three to five thousand and many of them were of Swabian origin, who definitely showed strong Nazi sentiments. Considering the possible connections with the local Jews and to avoid compassion the gendarme division from a different county set up the ghettos and led the deportation of the Jews. The police or the gendarmerie alone would not have been able to execute the anti-Jewish procedures without the support of public servants. ${ }^{38}$

The execution of the final solution also depended on the public administration bodies of the Hungarian state. That is why the Germans needed to establish a collaborator government. There were some county and town leaders or even police officers, who resigned rather than taking part in the persecution of the Jews. However, most local and county administrators, public servants and officers were more than happy to cooperate. There were only a few gerdames, like the state secretary's namesake chief staff sergeant, László Endre, who saved the lives of four hundred of Jews and non-Jews. After the war, he said that he -as someone from a large family- tried to imagine himself in the place of the inhuman situation of the persecuted masses and thus he was able to oppose to the orders. ${ }^{39}$ Gendarme colonel, László Ferenczy was of a different kind of example; the father of three was also known as the "Hungarian Eichmann". He came across the Auschwitz protocol first in June and he did ponder what goes on there; but by the time he made up his mind, it was too late: by then hundreds of thousands of people were already sent to death. ${ }^{40}$

36 BRAHAM, The Politics ... Chapter 3.: The Road to Destruction: The Sztójay Government and Its Agencies, 44-46. [in Hungarian: i.m. (2003) 55-57.]

37 MOLNÁR, Judit: Csendőrök a népbíróság előtt, in: A holokauszt Magyarországon európai perspektívában, Budapest 2005. Number of units see, Magyar Nemzeti Levéltár (Hungarian National Archives; hereinafter referred only as NA), fund BFL, B18 167/1949, carton, Czigány József pere, No. 96., MOL.

38 See BRAHAM, The Politics ... Chapter 3.: The Road to Destruction: The Sztójay Government and Its Agencies, 46. [in Hungarian: i.m. (2003) 57.]

39 MOLNÁR, Csendőrök ..., 660. For the role of László Endre see also: VÁGl, Zoltán: A másik Endre László [The other Endre László], in: Remény [Budapest] 1998. december, 47-53.

40 MOLNÁR, Csendőrök ..., 661. The role of László Ferenczy gendarme liutenant colonel see also MOLNÁR, Judit: "A magyar Eichmann", in: Csendőrtiszt a Markóban. Ferenczy László csendőr alezredes a népbíróság előtt, 
István Bibó argues that the Hungarian bureaucracy had a 'European side' that followed the law, they were professional and meticulous employees and not bossy or someone who does not respect human dignity. With their meticulous work, however, even this better half of the Hungarian bureaucracy had helped the application of Jewish laws. Therefore more than abiding the rule of law would have been needed from the time of the German occupation. "The assessment of the partial and later complete end of the political, ethical and legal validity of the state power would have been needed. Instead, even the 'more humane' part of bureaucracy was working in the spirit of following the legal actions of the legal Hungarian government." 41

Above I tried to summarize the essential historical researches concerning my topic. Based on them it is possible to follow the bureaucratic Anti-Semitism of the leaders of administrative units, and we also see the example of how easily Anti-Semitism transformed itself into bureaucratic Anti-Semitism. ${ }^{42}$

\section{The Holocaust through the Example of Mezöberény, a Hungarian Small Town}

Below I shall analyze the activities and operations of the public administration and the social context of the local anti-Semitism of Mezőberény, a small town during the spring of 1944 (the time of setting up the ghetto and the deportations) ${ }^{43}$. With the help of my research at the Békés County Archives of the National Archives of Hungary and the microfilm collection of National Széchenyi Library - based on assessing the administrative documents and articles of the period - I shall demonstrate through the example of Mezóberény that even on a local level beside the machinery of the administration the "bureaucratic AntiSemitism" played a main role in the process of the Holocaust in Hungary.

Mezőberény is located in the south-eastern region of the Great Hungarian Plane. Its size, with the peripheral lands is twenty thousand acres. In 1941, the population was 14,029 (and it was 11,564 according to the 2005 census). Mezóberény was mainly an agricultural community with no large estates: $70.2 \%$ of landowners possessed lands smaller than five hectares.

Three nationalities cohabit the town even today: Hungarians, Germans and Slovakians. The

MOLNÁR, Judit (ed.), Budapest 2014, 15-49.

41 BIBÓ, István: Zsidókérdés Magyarországon 1944 után, Budapest 2001.

42 See also: "I have met a county clerk in Budapest, namely dr. László Endre, who was burning from the desire to get rid of, as he said, of the Jewish plague. (...) a few days later (...) Endre as appointed by the new collaborator Sztójay-government (...) by Andor Jaross to take the position of the state secretary of public administration." see "Eichmann tells his own damning story", in: Life [American weekly magazin] 28 November and 5 December 1960., quoted by "Csendőrtiszt a Markóban" cited edition (2014) 82.

43 Several studies deal with the Holocaust of the countryside Jews. One of these tells the stories of Pécs; see SCHWEITZER, Gábor: A pécsi zsidóság gettósítása és deportálása Arató Jenő naplójegyzetiben, in: Velünk éltek - velünk élnek. Fejezetek a magyarországi és a Pécs-baranyai zsidóság történetéből, NAGY Mariann (ed.), Pécs 2015, 147-160. Concerning Szeged see MOLNÁR, Judit: 1944 - ünnepléstől deportálásig [1944: From Celebration to Deportation], in: Zsidók Szeged társadalmában [Jews in the Society of Szeged], TÓTH, István (ed.), Szeged 2014, 129-143. Regarding Szolnok and its region see LÁSZLÓ, Csősz: Jász-Nagykun-Szolnok megye [County Jász-Nagykun-Szolnok], in: A magyarországi holocaust földrajzi enciklopédiája [The Geographical Encyclopedia of the Holocaust in Hungary, BRAHAM, Randolph L. (ed.), Budapest 2007, 565-584. 
three nationalities had a great impact on the political identity of the town. The town was serving as an example for the nationalities living peacefully together for long. ${ }^{44}$ Israelites started to settle there from the end of 1830s, who claimed themselves German speaking until the end of the 1960s. In 1852 49, and in 1910280 Jewish inhabitants were conscribed. The Jewish community was established in 1851, which for a while functioned as status quo ante and then on congressional base. ${ }^{45}$

There township was home to a vigorous social struggle for centuries. In 1848 cotter movement emerged attracting the attention of the whole country. From 1891 the township became one of the main points of the agrarian socialist movement. In 1818-19 all the workers supported the left-wing power. Later, in the Horthy era, the left-wing movement had weakened and the local social democrats were striving to fulfil the will of the central leadership. ${ }^{46}$

Because of the growing influence of the radical right politics in the peace of the nationalities in Mezóberény had gradually dissolved; the majority of the German speakers of Mezőberény joined the radical right movements. The local radical right-wing group primarily threatened the left-wing powers. The majority of the township (80-85\% of adults) refused to take part in the arrow cross or volkbundist or any other similar movements. However, the social democrats due to their less favourable political and financial situation were unable to counter those efforts. The radical change came in the beginning of the 1930s; with the growing influence of the Smallholders' Party. The two above mentioned left wing parties were active in the political life of the township, were active but from the 1930s their activity was more moderate than of the Arrow Cross Party's, which was both supported by the local Germans and enjoyed the support of the government. ${ }^{47}$

The administration of the township primarily served the interests of the ruling class and the wealthy during the World War II. The suffrage in force ab ovo excluded the job seekers and homeless. Only the ones paying the communal tax were entitled to voting rights. Beside this limitation of the general right to vote, it also occurred that beside the elected members of the council many received a membership ex officio. Even these assurances had not satisfied the system: until the spring of 1945, virilism, ${ }^{48}$ the privileges of the wealthy was in force, which put openly and directly the wealthiest in to the important official positions. That is why the $50 \%$ of the council members were made of the ones paying the highest taxes, making them become members solely based on their wealth. ${ }^{49}$

At that time a 40-member representative body governed the township's council. They chose the prefects dealing with the everyday tasks and the judge heading them from their

44 See FARKAS, József: A világgazdasági válság végétől a község felszabadulásáig [From the end of the great global economic crisis up to the liberation of the village], in: Mezőberény története. 1. kötet [History Mezöberény. vol 1.], SZABÓ,Ferenc (ed.), Mezöberény, k.n. 1973, 353-395.

45 BONYHAI, Mihály: Mezőberény monográfiája [Monography on Mezőberény], Mezőberény 1934, 123-124.

46 FARKAS, 353.

47 Ibidem.

48 Virilism: special Prussian-origin political and legal principle in Hungary between the first and second Word War, according to which wealthy tax payers gets special rights, even disproportinate voting rights in local governments. 
members. The head of the office apparatus was the chief town clerk. The chief constable and the town clerks governed the local council, which represented the will of the county. ${ }^{50}$

\section{Finding the Local Factors of Deportation}

On 1 April 1944, thirty-one people were forced into a detention centre in Mezőberény; eighteen of them were Jewish men. In 1946, only Imre Grünwald and István Szegő returned. ${ }^{51}$ The main steps concerning the Holocaust in Mezöberény were the following:

April 5: decree of the obligation of wearing a yellow star;

May 8-10: inventory of assets;

May 12: escorting to a "forced residence" to the ghetto;

June 17: "leaving" the ghetto;

June 26: $\quad$ preparing the train transports to Auschwitz. ${ }^{52}$

The "forced residence" was in an unused weaving factory and an old brick factory at the border of the town. 153 people were forced into the ghetto including people also from the neighbouring Köröstarcsa. From the ghetto, people were transported to the concentration camp in Békéscsaba where later they were all crammed into cattle-cars. The train arrived in Auschwitz at around one o'clock in the afternoon. ${ }^{53}$

\section{The Validation of the Bureaucratic Anti-Semitism}

During the deportations in 1944 we find the same thing in all the January, March and April reports of the chief constables regarding the clerks of the township: the behaviour of the public servants is impeccable. My research focuses on these three months because, the decrees preceding the deportation already affected the Jews from the month of April, and the documents confirm how perfectly the clerks followed their orders.

On 26 April 1944 arrives the copy of the decree issued by state secretary Baky from the chief constable of Békés county "giving the point of orientation and utmost conformity." 54 The decree focuses on the cooperation with the German forces: "I am expecting from all the gendarmerie and police authorities an open and honest relationship towards the German police, in order to build the conditions for a comradely and fruitful cooperation". ${ }^{5}$ On 24 July 1944 the townships chief constable conveys the home office decree issued by minister Jaross. It reads that "People working in the administration in their capacity should avoid even the slightest suspicion that their work would not solely follow the universal

50 Ibidem, 353-395.

51 A magyarországi holocaust földrajzi enciklopédiája [The Geographical Encyclopedia of the Holocaust in Hungary], BRAHAM, Randolph L. (ed.), Budapest 2007, 236.

52 SZEGÖ, György: Két ima egy istenhez [Two Prayers to one God], Budapest 1999, 74-92.

53 A magyarországi holocaust ... , 236.

54 Magyar Nemzeti Levéltár Békés Megyei Levéltára (Hungarian National Archives of Békés County), Copy of the Decree of the Minister of the Interior issued by state secretay László Baky (the so called Baky Order).

55 lbidem. 
interest of the nation (...) In the official activity of the public servant to the must solely follow the general national interest, ignoring all aspects of party politics." 56 The administrative summons seemingly aims at making officials do their duty out of a conviction that they are working for the interest of the nation.

On 26 April 1944 state secretary Baky issued another home office decree which was conveyed by the Békés county chief constable to the chief notary of the township. This decree was about the cooperation between the Hungarian authorities and the German armed forces and police. "Obviously it is the Jewish question causing the frictions, so as a point of reference please note that it will be solved on a national and institutional scale, no individual deviation is part of the plan, it is not to be tolerated from neither side. This cannot be understood that the German armed and police forces couldn't eliminate a few Jews, whom threaten the universal interest of the German army and of the Hungarian nation. Where there was harmony between the bodies and authorities there were no complaints in this regard; and when I was informed in due time of some exaggerated local solutions taking shape, I found the way to put an end to it with the local German forces. "57 Reading through these lines, it is impossible not to see the anti-Semitic tenets and the encouraging of the armed forces to it. The last sentence confirms that there were instances fuelled by anti-Semitism of individuals attempting to solve the question by themselves.

The 3 July 1944 report of the town clerk of Mezóberény shows that on one hand they concerned the activities regarding the solving of the Jewish question central and on the other hand even a month after the deportations they were still intrigued whether they should get any more orders in the ominous question from the higher levels. According to the report "directly no ministry regulation with regard to the Jewish issues was issued here." ${ }^{\prime 58}$

The above-mentioned documents "only" prove the expectations of administrative performance, and the fact that the local administration complied perfectly with what was expected of them. However, we should not ignore the critical fact that "the Holocaust was the extreme manifestation of a century-long Hungarian tradition", ${ }^{59}$ centred on antiSemitism. For this reason in the followings, I shall examine the relationship of the society of Mezóberény to the Jews prior to the Holocaust.

56 Magyar Nemzeti Levéltár Békés Megyei Levéltára (Hungarian National Archives of Békés County), Copy of the Decree of the Minister of the Interior issued by state secretay Andor Jaross.

57 Magyar Nemzeti Levéltár Békés Megyei Levéltára (Hungarian National Archives of Békés County), Copy of the Decree of the Minister of the Interior issued by state secretay László Baky (the so called Baky Order).

58 Report of the town clerk from Mezőberény, 3 July 1944.

59 KÁDÁR, Gábor - VÁGl, Zoltán: A végső döntés [The final decision (Endlösung)], Budapest 2013, 250. In more detail: "This is non-integrated narrative of national memory that breaks to surface in different forms. The core idea of it is maybe the violence, etnocentrism, ethnical and religious based intolerance, imperial self-awareness, the notion of being extraordinary - the Hungarian nation, the cultural supremacy, the racism, the racial supremacy, the wish for ethnical homogenity, the anti-Judaism and the anti-Semitism, the pogroms, the discrimination and the race protection (...) all of them came to the surface from the Middle-Age till the $20^{\text {th }}$ century in the expulsion of Jews, in the conception legal actions against Gypsies and Izraelites, in the ethnical conflicts fought with the nationalities of Hungary, in the inpatience against the fight for autonomy of the ethnicities of the country, and in the strengthening desire toward ethnical cleansing." Ibidem. 


\section{Anti-Semitism as a Social Attitude}

In this part of my paper I shall examine how anti-Semitism conceived in the local community during the years before the Holocaust. The initiators of the arrow cross movement acquired the township's media - Alföldi Függetlenség, a regional political weekly in 1934. Right then the spread of anti-Semitic views had started in the local newspaper, ${ }^{60}$ where the tenets of József N.Schultz, the leader of the local arrow cross party were the most noticeable. According to Schultz, Jews were the source of all the problems: "The lost war, Trianon, unemployment, a series of suicides would not happen if it wasn't for them. "61

"The people will never know the truths about Hitler until the honest and the ones with logic among them are not informed about the horrible organization on Jewish hand, which with its invisible hands has been making revolutions and has chased the world into that horrible war benefiting only the capitalist and communist Jews, which left us with ten millions dead and a hundred times more in destitute. The Jewish led international freemasons is the curse on the body of all nations, with its hand reaching not only to Paris or Prague but also to Mezőberény, they attack from behind and do not take the responsibility, and that is what they call intellectual superiority. [...] The lost war, Trianon, faction, unemployment, a series of suicides would not happen if it wasn't for them."62

The anti-Semitism of N. Schultz ended in an assault in 1934 when he attacked a man called Weiszbrunn for no particular reason. The court had convicted him for it. In the "argument the court stated that Weiszbrunn was hit from behind thus it must have been N.Schultz who started the fight. According to the court practice and the law, N.Schultz had to be punished and the other defendant to be acquitted."63

The organization went so well that the party's conference was held in Mezöberény on 18-19 January 1936. It was also advantageous that there was no obstacle to legal agitation, neither the township nor the council obstructed the spreading of the fliers; the Arrow Cross Party were free to do whatever they wished.

Szálasi's supporters and scythe crossers also appeared in the county but the forces had restricted their activities and therefore their movement was not significant. They held a rally on 20 March 1935 in Mezöberény where the leader of the party, Zoltán Böszörményi spoke. ${ }^{64}$ These examples support that the radical right agitated by using rather dangerous tools. The names of local leaders were also known in the national movement and the local organization had the goal of strengthening the racial consciousness and of the Germans. With the leading of N. Schultz, they established a core group of two hundred men where every guard member

60 Zsolt Bódán reached a similar conclusion when he examined another local newspaper (titled "Békés", published in city of Gyula). See A holokauszt Békés megyei történeteiből [Stories of the Holocaust in Bekes County], in: Gyula: Magyar Nemzeti Levéltár Békés Megyei Levéltára, ERDÉSZ, Ádám - KOVÁCS, Tamás (eds.), Gyula 2014. 32-54. According to him anti-Semitic sentiments in the newspapers were present throughout the period, although they intensified in the pre-war years.

61 Alföldi Függetlenség, 1934, vol. XIV, No. 24, 17 June.

62 Alföldi Függetlenség, 1934, vol. XIV, No. 27, 8 July.

63 Alföldi Függetlenség, 1934, vol. XIV, No. 31, 14 October.

64 Gyula Törvénytárának archívuma (Archives of the Tribunal of Gyula), Békésmegyei Közlöny [Gazette of County Békés], 17 February 1938, No. B 3898/1937. 
was responsible for four other party members, thus they were able to mobilize even a thousand people. ${ }^{65}$

From the summer of 1940 of the leaders of the arrow cross started organizing Volksbund and again there was N. Schultz in their leadership. Their activities brought a quick success, because their operation was guaranteed by an international agreement and they also managed reach that they were completely free from police control. The 46 members in the beginning soon became 598. Recruiting for the SS was their main activity. Those who did not want to join the SS or the Volksbund were often bullied and threatened. The freshly recruited SS members took part in multiple anti-Jewish "demonstrations" in 1943 such as breaking windows and ravaging the Jewish cemeteries. ${ }^{66}$

Jews were expelled from the council in 1939, and later they were forbidden to acquire a trade certificate in the county of Békés. ${ }^{67}$ Being banned from the county's market was followed by segregation; the ghetto was designated in the halls of the Weisz weaving factory. ${ }^{68}$

Fascist groups emerged in the township already after the years of the great depression. The agitators of the movements mainly spread the idea of social demagogy and anti-Semitism. The peaceful coexistence of the three nationalities was broken after many among the German speaking community became conscious of their "superiority". The aforementioned radical right activity attracted about $20 \%$ of the community but because of their violence and strong propaganda the outsiders often felt that the majority is under the influence of the right. One of the lowest points in the history of the town was when Mezőberény became the country's arrow cross centre.

\section{Conclusion}

In this study, I was seeking for the main reasons that triggered the phenomenon of Holocaust in Hungary. With regard to the different views, Bauman's theory is of utmost significance. Bauman considers bureaucracy - as one of the achievements of modernity - the main cause triggering the Holocaust; more specifically, he argues for bureaucracy to be the only actor. However, this statement does not prove right when considering the Hungarian events.

I have highlighted the main features of bureaucracy through administrative documents and also looked into the significance of anti-Semitism the local social context. I examined the administrative documents and newspapers articles published in Mezóberény, Békés County, and highlighted how the radical right-wing ideology had set their foot already in the 1930s; furthermore I have shown the kinds of anti-Jewish activities of the radical right-wing movements in the 10-12 years prior to the Holocaust, and how these created the "right" social condition for the deportations in 1944.

During my analysis I came to the conclusion that the main factor triggering the Holocaust in Hungary was not bureaucracy, but anti-Semitism, even though, by looking at the entire process of the Hungarian Holocaust, the key to the efficiency of the machinery lay in the

65 Political destiny of Tiszántúl region (editorial), in: Magyar Szemle [Hungarian Review (national cultural journal between 1927 and 1944)], 1938, No.5 (May), 1.

66 Történelmi Szemle [Historical Review (scientific journals)], 1968, No.11, 294-312.

67 Békési Újság [Békés' News (daily local newspaper)],1940, 10 February.

68 Békési Újság [Békés' News (daily local newspaper)], 1944, 13 May. 
parallelism and duality of the two factors. My argument is based on the insight that although Hungary was under German influence, the acceptance of their ideological views, namely the identifying of Jews as the common enemy, was not the direct consequence of the influence. So we can argue that the main triggering factor of the Holocaust was the strong anti-Semitism of the Hungarian society. Thus interiorizing the German racism Hungary had mobilized its administrative apparatus and the public servants in order to "solve the Jewish question".

\section{References}

Gyula Törvénytárának archívuma (Archives of the Tribunal of Gyula), Békésmegyei Közlöny [Gazette of County Békés], 17 February 1938, No. B 3898/1937.

Magyar Nemzeti Levéltár (Hungarian National Archives, fund BFL, B18 167/1949.

Magyar Nemzeti Levéltár Békés Megyei Levéltára (Hungarian National Archives of Békés County), A Belügyminisztérium körrendelete a magyar hatóságok és a német fegyveres alakulatok között kialakítandó együttmúködés irányelveiről (Order of the Home Office about the guidelines of cooperation between the Hungarian authorities and the German armed forces).

Magyar Nemzeti Levéltár Békés Megyei Levéltára (Hungarian National Archives of Békés County), Copy of the Decree of the Minister of the Interior issued by state secretay László Baky (the so called Baky Order).

Magyar Nemzeti Levéltár Békés Megyei Levéltára (Hungarian National Archives of Békés County), Copy of the Decree of the Minister of the Interior issued by state secretay Andor Jaross.

Alföldi Függetlenség, 1934, vol. XIV, No. 24, 17 June.

Alföldi Függetlenség, 1934, vol. XIV, No. 27, 8 July.

Alföldi Függetlenség, 1934, vol. XIV, No. 31, 14 October.

Békési Újság, 1940, 10 February.

Békési Újság, 1944, 13 May.

Life [American weekly magazin] 28 November and 5 December 1960., quoted by "Csendőrtiszt a Markóban" cited edition (2014) 82.

Magyar Szemle, 1938, No. 5 (May).

Pester Loyd [Hungarian daily paper in German] 1944. április 1. quoted in Vádirat a nácizmus ellen [Indictment against Nazism] cited edition [id. kiad.] 200.

Történelmi Szemle, 1968, No.11.

ARENDT, Hannah: The Origins of Totalitarianism, Cleveland and New York 1968.

ARENDT, Hannah: A totalitarizmus gyökerei [The Origins of Totalitarianism], Budapest 1992.

ARENDT, Hannah: Eichmann Jeruzsálemben [Eichmann in Jerusalem], Budapest 2000.

ARENDT, Hannah: Eichmann in Jerusalem, New York 2006, 136.

BAUER, Yehuda: Átfogó elméletek: [Complete theories: Daniel J. Goldhagen, John Weiss, Saul Friedländer], in: Holokauszt: történelem és emlékezet [Holocaust: History and Memory], KOVÁCS, Mónika (ed.), Budapest 2005.

BAUMAN, Zygmunt: Modernity and the Holocaust, Cambridge-Maldon1989. 
BAUMAN, Zygmunt: A modernitás és a holokauszt [Modernity and the Holocaust]. Budapest 2001.

BIBÓ, István: Zsidókérdés Magyarországon 1944 után [Jewish Question in Hungary after 1944], Budapest 2001.

BÓDÁN, Zsolt: "BÉKÉS" antiszemitizmus A zsidókérdés egy gyulai napilapban az 1930as évek végén [Jewish question in a local newspaper of Gyula towards the 1930'], in: A holokauszt Békés megyei történeteiból. [Some stories of Holocaust in Bekes County], ERDÉSZ, Ádám - KOVÁCS, Tamás (eds.), Gyula 2014.

BONYHAl, Mihály: Mezőberény monográfiája [Monography on Mezőberény], Mezőberény 1934.

BRAHAM, Randolf L.: The Politics of Genocide: The Holocaust in Hungary. Detroit Michigan 2000.

BRAHAM, Randolf L.: A népirtás politikája [The Politics of Genocide: The Holocaust in Hungary], Budapest 2003.

BRAHAM, Randolf L.: A magyarországi holokauszt földrajzi enciklopédiája [The Geographical Encyclopedia of the Holocaust in Hungary], 2008.

BROWNING, Christopher R.: The German Bureaucracy and the Holocaust, in: Genocide: Genocide: Critical Issues of the Holocaust, GROBMAN, Alex-MILTON, Sybil - LANDES, Daniel, (eds.), Los Angeles 1983.

CSŐSZ, László: Jász-Nagykun-Szolnok megye, in: A magyarországi holocaust földrajzi enciklopédiája [The Geographical Encyclopedia of the Holocaust in Hungary], BRAHAM, Randolph L. (ed.), Budapest 2007.

DUBY, Georges (ed.): Franciaország története 2. [History of France. vol. 2.] Budapest 2007.

DU GAY, Paul: Praise of Buraucracy Sage Publications, London-Thousand Oaks-New Delhi, 2000.

FARKAS, József: A világgazdaság végétől a község felszabadulásáig [From the end of the global economic crisis of 1928-32 up to the liberation of the village in 1945], in: Mezöberény története. 1. kötet [History Mezóberény. vol 1.], SZABÓ, Ferenc (ed.), Mezőberény, k.n. 1973.

GERLACH, Christian - GÖTZ, Aly: The Last Chapter. Realpolitik, Ideology and the Routine Killing of Hungarian Jews 1944/1945, Stuttgart-München 2002.

GIDDENS, Anthony: Szociológia [Sociology], Budapest 2008.

GÖTZ, Aly: Hitler's Folk State: Robbery, Ethnic War and National Socialism, 2012.

HILBERG, Raul: The Destruction of The European Jews, New York 1983.

KÁDÁR, Gábor - VÁGI, Zoltán: A végső döntés. [The final decision (Endlösung)], Budapest 2013.

KANT, Immanuel: Az erkölcsök metafizikájának alapvetése. A gyakorlati ész kritikája. Az erkölcsök metafizikája. [Grundlegung zur Metaphysik der Sitten], Gondolat, Budapest 1991 [Berliner Ausgabe, 4. Auflage, 2016].

KARSAI, Elek: A budai vártól a gyepúig. 1941-1945 [From Buda Castle to the frontier zone. 1941-1945], Budapest Táncsics 1965.

KARSAI Elek: Ítél a nép. Budapest, Kossuth 1977.

KARSAI, László - MOLNÁR, Judit: Endre-Baky-Jaross per [The Endre-Baky-Jaross case],Budapest 1994.

MACARTNEY, Carlile Aylmer: October fifteenth. A history of modern Hungary, 1929-1945, 
vol. 2, Edinburgh 1956-57.

MOLNÁR, Judit: A holokauszt Magyarországon európai perspektívában [The Holocaust in Hungary in European Perspective], Budapest 2005.

MOLNÁR, Judit: 1944 - ünnepléstől deportálásig [1944: From Celebration to Deportation], in: Zsidók Szeged társadalmában [Jews in the Society of Szeged], TÓTH, István (ed.), Szeged 2014.

MOLNÁR, Judit (ed.): Csendőrtiszt a Markóban. Ferenczy László csendőr alezredes a népbíróság elött [A gendarme officer before the High Criminal Court. Lt. Col. László Ferenczy before the people's court], Budapest 2014.

SCHWEITZER, Gábor: A pécsi zsidóság gettósítása és deportálása Arató Jenő naplójegyzetiben. [Ghettoization and deportation of Jews in Pécs as reported in Arató Jenő's diary], in: Velünk éltek - velünk élnek. Fejezetek a magyarországi és a Pécs-baranyai zsidóság történetéból. [They lived with us - They live with us. Chapters from the History of Jews of Hungary and that of Pécs and County Baranya], NAGY, Mariann, (ed.), Pécs 2015.

SZEGŐ, György: Két ima egy istenhez [Two Prayers to one God], Budapest 1999.

SZITA, Szabolcs: Együttélés, Üldöztetés, Holokauszt [Coexistence, Persecution, Holocaust],

Budapest 2001.

TAKÁCS, Péter: Hostis humani generis. A joghatóság és a büntethetőség problémái a Finta-ügyben [Hostis humani generis. Problems of jurisdiction and criminal responsibility in Finta case]. in: Fundamentum [Budapest] 2001, 4.

UNGVÁRY, Krisztián: A Horthy-rendszer mérlege. Diszkriminció, szociálpolitika és antiszemitizmus Magyarországon 1919-1944. [Balance of the Horty regime. Discrimination, socialpolitics, anti-Semitism.], Pécs-Budapest 2013.

VÁGI, Zoltán: A másik Endre László [The other Endre László], in: Remény [Budapest] 1998, december.

VÁGI, Zoltán: Endre László. Fajvédelem és bürokratikus antiszemitizmus a közigazgatási gyakorlatban, 1919-1944 [Endre László: Racial protection and bureaucratic anti-Semitism in administrative practice, 1919-1944] in: Tanulmányok a holokausztról. 2. kötet [Studies on Holocaust. vol. 2], BRAHAM, Randolph L. (ed.), Budapest 2002.

WEBER, Max: Politik als Beruf(1921), Tübingen 1988.

WEBER, Max: A tudomány és politika, mint hivatás. [Wissenschaft und Politik als Beruf], 1989.

WEBER, Max: Witrschaft und Gesellschaft. Grundriss der verstehenden Soziologie, Frankfurt am Main 2005.

WEBER, Max: Politikai szociológia. Politikai közösségek. Az uralom. [Political Sociology. Political Communities. Authority], Budapest 2009.

\section{Author}

Éva Gulyás

Nemzeti Közszolgálati Egyetem, Közigazgatás-tudományi Doktori Iskola

National University of Public Service, Doctoral School of Public Administration Sciences

Ménesi u. 5, H-1118 Budapest, Hungary

Gulyas.Eva@uni-nke.hu 